\title{
Matrix Metalloproteinases-2, $-3,-7,-9$ and -10 , But Not MMP-11, Are Differentially Expressed in Normal, Benign Tumorigenic and Malignant Human Keratinocyte Cell Lines
}

\author{
Beatrice E. Bachmeier' ${ }^{1}$ Petra Boukamp², \\ Ralf Lichtinghagen ${ }^{3}$, Norbert E. Fusenig ${ }^{2}$ and \\ Edwin Fink ${ }^{1, *}$ \\ ${ }^{1}$ Department of Clinical Chemistry and Clinical \\ Biochemistry, University Hospital of Surgery, \\ Ludwig-Maximilians-University, Nussbaumstr. 20, \\ D-80336 Munich, Germany \\ ${ }^{2}$ Division of $\mathrm{C}$ arcinogenesis and Differentiation, \\ German Cancer Research Center, \\ Im Neuenheimer Feld 280, D-69120 Heidelberg, \\ Germany \\ ${ }^{3}$ Institute of C linical Chemistry I, \\ Medizinische Hochschule, Carl-Neuberg-Str. 1, \\ D-30623 Hannover, Germany \\ *Corresponding author
}

In order to investigate the correlations between constitutive proteinase expression and the degree of tumorigenicity of cancer cells we have studied a model system of three keratinocyte cell lines. RT-PCR studies showed that the cell lines express the genes of matrix metalloproteinase- $2,-3,-7,-9,-10$ and -11 , indicating that they are able to synthesize the corresponding enzymes. Actual MMP synthesis was proven by zymography and Western blotting. In conditioned media gelatinolytic activities or immunoreactive forms of MMP-2, -3, -7, -9, -10 and -11 were detected. The signal intensities showed that MMP secretion increases in the order HaCaT $<$ A5 $\leq$ II-4RT, whereas only MMP11 is secreted by all cell lines in equal amounts. Intracellularly, enhanced levels of one or both of the tumorigenic variants were only found for MMP-3, -9 and -10 , suggesting special functions of these intracellular MMP pools for the tumorigenic cell lines. For MMP-11 exclusive expression in stromal fibroblasts of tumor tissues is widely accepted; however, our results and three other recent reports demonstrate that this concept is not generally valid. In conclusion, the three keratinocyte cell lines investigated here represent an excellent model for studying constitutive expression and secretion of MMPs in correlation to the degree of in vivo tumorigenicity.

Key words: Collagenases / Gelatinases / HaCaT cells / Matrilysin / Stromelysins.

\section{Introduction}

A large and expanding number of proteinases is currently being recognized as contributing to the complex processes of tumor invasion and metastasis (Schmitt et al., 1992; Mignatti and Rifkin, 1993; Sloane and Berquin, 1993). The various proteinases, which are produced by tumor and/or host cells, are involved in an only partly understood manner in the many steps of tumor progression, such as growth of primary and secondary tumor, tissue invasion, angiogenesis, and intra- and extravasation of cancer cells.

Among the proteinases especially the matrix metalloproteinases (MMP), particularly gelatinases $A$ and $B$ (MM P-2 and -9), stromelysins- 1 and -2 (MMP-3, -10) and matrilysin (MMP-7), have been implicated in the degradation and remodeling of extracellular matrix and especially the basement membranes (Mignatti and Rifkin, 1993; Stetler-Stevenson et al., 1993; Ray and Stetler-Stevenson, 1994; Noël et al., 1997). The MMPs have different substrate specificities and, by their redundant and cooperative action, all components of the extracellular matrix and basement membrane can be degraded. Stromelysin-3 (MMP-11), for whose expression interesting correlations with matrix remodeling and breast cancer recurrence have been observed, does, nevertheless, not degrade extracellular matrix components and its physiological substrates are as yet unknown (Pei and Weiss, 1998).

Evidence supporting the view that MMPs are important in all stages of tumor progression including growth, invasion, metastasis and angiogenesis comes from the following observations: (i) elevated MMP levels or mRNA expression in tumor biopsies are associated with an enhanced degree of malignancy (Schmitt et al., 1992; Karameris et al., 1997); (ii), in in vivo studies an overexpression of MMPs in non-invasive cell lines caused an increase of the metastatic potential (Knox et al., 1993; Powell et al., 1993; Bernhard et al., 1994; (iii), the intraperitoneal administration of the MMP inhibitor TIMP-1 reduced lung colonization of intravenously injected B $16 f 10$ melanoma cells (Schultz et al., 1988); and (iv) when TIMP1 levels were reduced in cells by antisense RNA, formation of metastatic tumors in nude mice was increased (Khokha et al., 1989; Watanabe et al., 1996), while tumor progression and tumorigenesis were reduced in MMP-2 and MMP-11 null mice, respectively (Itoh et al., 1998; Masson et al., 1998). 
In addition to degrading extracellular matrices there are now strong indications that MMPs and their inhibitors contribute significantly to the initiation and sustenance of tumor growth, based for example on the release and activation of growth factors, direct involvement in cell locomotion, and processing and shedding of cell surface proteins (Koop et al., 1994; Morris et al., 1994; Chambers and Matrisian, 1997; Noël et al., 1997). Taken together, evidence derived from different experimental approaches strongly supports an important role of M MPs in malignant invasion and metastatic spread, based on their ability to degrade physical barriers or on other proteolytic events.

Studies like those referred to above demonstrate that elevated MMP levels in cancer tissues are due to increased production by epithelial tumor cells and/or their neighboring stromal cells (Liaw and Crawford, 1999). With the aim to establish an in vitro cell model for studying the correlations between the degree of tumorigenicity of epithelial cells and the constitutive proteinase production, we investigated whether the differences in tumorigenicity of three closely related human keratinocyte cell lines are reflected in their profiles of expressed MMPs. The cell lines employed were $\mathrm{HaCaT}$, a spontaneously immortalized human keratinocyte cell line (Boukamp et al., 1988), and the two clones $\mathrm{A} 5$ and II-4RT, which were derived from $\mathrm{HaCaT}$ by stable transfection with cellular Ha-ras oncogene. The in vivo tumorigenicity of all cell lines has been thoroughly characterized (Boukamp et al., 1990) (cf. Discussion). Thus, the three cell lines represent a unique model of closely related cells with defined tumorigenicities, and comparative analyses of constituents and secreted products of these cell lines should provide valuable indications on correlations between the grade of tumorigenicity and the expression of functionally important parameters, such as proteinases.

In the present study we demonstrate that the mRNAs of MMP-2, $-3,-7,-9,-10$ and -11 are expressed by all three cell clones and that, except for MMP-11, the corresponding proteins are differentially produced and secreted by the cell lines as revealed by semi-quantitative zymography and Western blot analyses.

\section{Results}

\section{Morphology of Cultured Cells}

Freshly seeded $\mathrm{HaCaT}$ cells adhered to the surface of the culture dish within one hour and formed islets of about 10 - 20 cells. After 3 - 4 hours the cells exhibited a flat, polygonal shape which is typical for cultured keratinocytes. The cells grew as monolayer and reached about 30 and $95 \%$ confluence after $23 \mathrm{~h}$ and 9 - 11 days, respectively. A5 cells, which are somewhat smaller in size than $\mathrm{HaCaT}$, grew in a quite similar manner.

$\mathrm{HaCaT}$ II-4RT also adhered within one hour after seeding, but in contrast to $\mathrm{HaCaT}$ they formed islets of stratifying cells. The typical polygonal shape appeared after about $45 \mathrm{~h}$. Instead of monolayer formation as observed with $\mathrm{HaCaT}$ and A5, II-4RT cells exhibited marked stratification. Therefore, II-4RT cells were harvested at about $80 \%$ confluence which was reached after about 14 days.

\section{Expression of $\mathrm{mRNA}$ of Metalloproteinase-2,}

\section{$-3,-7,-9,-10$ and -11}

Semi-nested RT-PCR assays were developed for detecting expression of the mRNAs of M MP $-2,-3,-7,-9,-10$ and

Table 1 Oligonucleotide Primers Used for RT-PCR.

\begin{tabular}{|c|c|c|c|}
\hline Primer & & Sequence & Location \\
\hline MMP-2 & $\begin{array}{l}\text { forward } \\
\text { outer reverse } \\
\text { inner reverse }\end{array}$ & $\begin{array}{l}\text { 5'-GACCACAGCCAACTACGATG-3' } \\
\text { 5'-GTGTATCGAAGGCAGTGGAG-3' } \\
\text { 5'-GGTTCTCCAGCTTCAGGTAA-3' }\end{array}$ & $\begin{array}{l}\text { exon } 7 \\
\text { exon } 13 \\
\text { exon } 13\end{array}$ \\
\hline MMP-3 & $\begin{array}{l}\text { forward } \\
\text { outer reverse } \\
\text { inner reverse }\end{array}$ & $\begin{array}{l}\text { 5'-GTGAGGACACCAGCATGAAC-3' } \\
5^{\prime} \text {-CTCAGAGTGCTGACAGCATC-3' } \\
5^{\prime} \text {-GAGTCAGGTCTGTGAGTGAG-3' }\end{array}$ & $\begin{array}{l}\text { exon } 1 \\
\text { exon } 6 \\
\text { exon } 5\end{array}$ \\
\hline MMP-7 & $\begin{array}{l}\text { forward } \\
\text { outer reverse } \\
\text { inner reverse }\end{array}$ & $\begin{array}{l}\text { 5'-GCATGAGTGAGCTACAGTG-3' } \\
\text { 5'-TGGAGTGGAAGAACAGTG-3' } \\
\text { 5'-GGATGTTCTGCCTGAAGT-3' }\end{array}$ & $\begin{array}{l}\text { exon } 1 \\
\text { exon } 6 \\
\text { exon } 6\end{array}$ \\
\hline MMP-9 & $\begin{array}{l}\text { forward } \\
\text { outer reverse } \\
\text { inner reverse }\end{array}$ & $\begin{array}{l}\text { 5'-GCAGACATCGTCATCCAGTT-3' } \\
\text { 5'-GAAGATGTTCACGTTGCAGG-3' } \\
\text { 5'-GCACAGTAGTGGCCGTAGAA-3' }\end{array}$ & $\begin{array}{l}\text { exon } 3 \\
\text { exon } 9 \\
\text { exon } 9\end{array}$ \\
\hline MMP-10 & $\begin{array}{l}\text { forward } \\
\text { outer reverse } \\
\text { inner reverse }\end{array}$ & $\begin{array}{l}\text { 5'-TCCTTGTGCTGTTGTGTCTG-3' } \\
5^{\prime} \text {-TCAACCTTAGGCTCAACTCC-3' } \\
5^{\prime} \text {-GATGCCTCTTGGATAACCTG-3' }\end{array}$ & $\begin{array}{l}\text { exon } 1 \\
\text { exon } 9 \\
\text { exon } 8\end{array}$ \\
\hline MMP-11 & $\begin{array}{l}\text { forward } \\
\text { outer reverse } \\
\text { inner reverse }\end{array}$ & $\begin{array}{l}\text { 5'-GAAGACGGACCTCACCTACA-3' } \\
\text { 5'-CAGAGCCTTCACCTTCACAG-3' } \\
\text { 5'-GGAAGTAGGCATAGCCATCA-3' }\end{array}$ & $\begin{array}{l}\text { exon } 2 \\
\text { exon } 10 \\
\text { exon } 9\end{array}$ \\
\hline
\end{tabular}


Table 2 Sizes of PCR Products and Their Restriction Fragments.

\begin{tabular}{lcll}
\hline & $\begin{array}{l}\text { Size of PCR } \\
\text { product (bp) }\end{array}$ & $\begin{array}{l}\text { Restriction } \\
\text { endonucleases }\end{array}$ & $\begin{array}{l}\text { Sizes of restriction } \\
\text { fragments (bp) }\end{array}$ \\
\hline MMP-2 & 800 & Pstl & 60,740 \\
MMP-3 & 665 & Styl/Ddel & $57,134,474$ \\
MMP-7 & 748 & BstNI & $30,82,198,438$ \\
MMP-9 & 1033 & Styl & $288,352,393$ \\
MMP-10 & 1109 & Fokl & $4,105,121,879$ \\
MMP-11 & 1031 & Styl & $35,98,179,334$ \\
& & & 385 \\
\hline
\end{tabular}
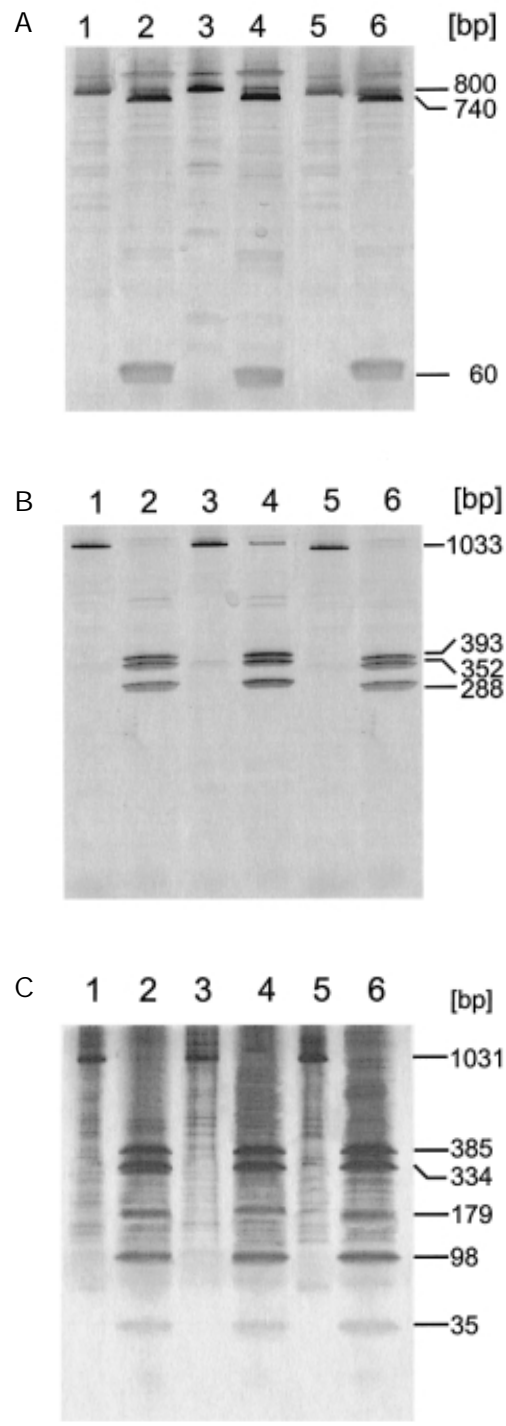

Fig. 1 Expression of MMP mRNAs Demonstrated by SemiNested RT-PCR.

Data are shown for MMP-2 (1A), MMP-9 (1B) and MMP-11 (1C). Reverse transcription and semi-nested PCR were performed with total RNA from about $10^{6}$ cells of each cell line. Aliquots of PCR mixtures before (lanes 1, 3 and 5) and after digestion with restriction endonucleases (lanes 2, 4 and 6) along with a DNA size standard (lanes not shown) were subjected to PAGE. In each gel lanes 1 and 2 represent the results of $\mathrm{HaCaT}$, lanes 3 and 4 of $A 5$, and lanes 5 and 6 of II-4RT cells. The sizes of PCR products and restriction fragments (cf. Table 2 ) are indicated.
- 11 with high specificity and sensitivity. P rimers were chosen in such a way that the PCR amplicon included exonexon transitions (Table 1); thus, amplification of any genomic DNA contaminating the cDNA preparations would result in intron-containing products that could be easily recognized by theirsize. The possibility that the amplicons might result from retropseudogenes of contaminating genomic DNA was also excluded for all four MMPs: when PCRs were carried out with genomic DNA the products were in all cases either longer than those of CDNA or no product at all was obtained (data not shown). Further identification of the amplicons was achieved by digestion with appropriate restriction endonucleases (Table 2, Figure 1). Taken together, the combination of the control experiments guarantees the unequivocal identification of the six MMP mRNAs by the RT-PCR procedure.

Analysis by RT-PCR of total RNA isolated from the three cell lines demonstrated that all of them express mRNAs of MMP-2, $-3,-7,-9,-10$ and -11 and are, therefore, capable of synthesizing the corresponding MMPs.

\section{Gelatinolytic Activity in Cell Extracts}

Gelatin zymography of cell extracts revealed that each of the three cell lines contained gelatinolytic activity (Figure 2). The main lysis bands appeared at positions corresponding to 72 and $65 \mathrm{kDa}$; in some experiments three to four minor bands were visible between 50 and $57 \mathrm{kDa}$. The gelatinolytic activity was completely suppressed when the gel was incubated in the presence of $2 \mathrm{~mm}$ EDTA or $1 \mathrm{~mm}$ o-phenanthroline, but not when PMSF, leupeptin or E64 were added. Thus, all bands were identified as metalloproteinases. As judged from their positions the lysis zones at $72 \mathrm{kDa}$ and $65 \mathrm{kDa}$ represent pro- and active MMP-2, while the other bands may be due to various forms of MMPs that became activated during the extraction procedure or sample preparation.

\section{Gelatin Zymography of Conditioned Media}

In order to investigate secretion of MMPs by the three cell lines serum-free conditioned media were collected, con-

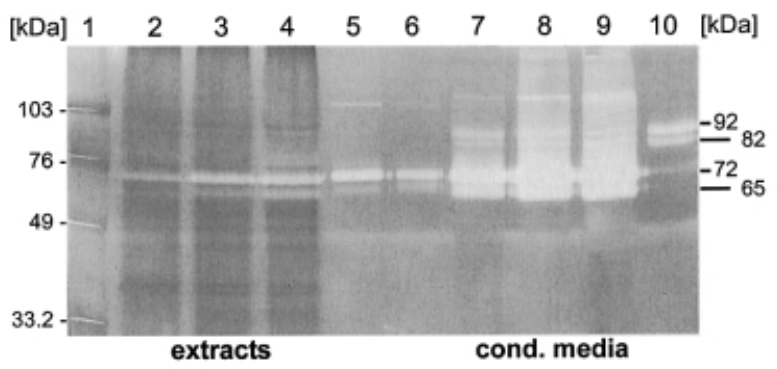

Fig. 2 Gelatin Zymography of Cell Extracts and Conditioned Media.

Lane 1, marker proteins; lanes $2-4$, extracts of $\mathrm{HaCaT}$, A5 and II4RT cells ( $30 \mu \mathrm{g}$ protein per lane); lanes 5 and 6 , conditioned medium of NB-4 cells (MMP- 2 control) before and after activation by APMA treatment; lanes 7 - 9, conditioned media of $\mathrm{HaCaT}$, A5 and II-4RT cells $(15 \mu \mathrm{g}$ protein per lane); lane 10 , conditioned medium of human foreskin fibroblasts (M MP- 9 control). 
centrated and aliquots with equal amounts of protein subjected to the zymography procedure. When $15 \mu \mathrm{g}$ of protein from supernatants of the three cell lines were applied, for all cells lysis zones at positions corresponding to molecular masses of $92,82,72,65$ and $45 \mathrm{kDa}$ were obtained (Figure 2). To identify the lysis zones their positions were compared with those of media from NB-4 cells and foreskin fibroblasts (with and without APMA activation), as these cells constitutively secrete pro-MMP-9 and proMMP-2, respectively. This comparison clearly showed that the lytic zones at 92 and $82 \mathrm{kDa}$ correspond to latent and active MMP-9, and those at 72 and $65 \mathrm{kDa}$ to the zymogen and active form of MMP-2 (Figure 2). A band of high molecular mass observed near the start probably represents a dimer of M M P - 9 (160 kDa). All activity bands disappeared almost completely when $2 \mathrm{mM}$ EDTA was added to the washing and incubation solutions, indicating that the bands represented MMPs. Remaining diffuse, faint lysis zones were obviously not due to metalloproteinase activity.

When 5, 10 and $15 \mu \mathrm{g}$ protein per lane were applied to the gels, visual examination of the zymograms indicated that the gelatinolytic activity was lowest in $\mathrm{HaCaT}$ media and increased with tumorigenicity of the cells (data not shown). For a quantitative comparison of the proteolytic activities, zymograms of conditioned media from two cell culture experiments were densitometrically evaluated. In these experiments bands of MMP-2 appeared at 65 and $60 \mathrm{kDa}$, and not at 72 and $65 \mathrm{kDa}$ as in the experiment shown in Figure 2 . This is probably due to the fact that the bands of the prestained molecular mass markers were not marked by a small cut in the gel immediately after electrophoresis (visible in Figure 2), but the maxima of intensities observed after staining were used for the calculation. The positions of these maxima differ slightly from those of the cut marks due to the diffusion of the marker bands during the incubation procedures. Nevertheless, there is no doubt that the lysis zones at 65 and $60 \mathrm{kDa}$ represent pro-

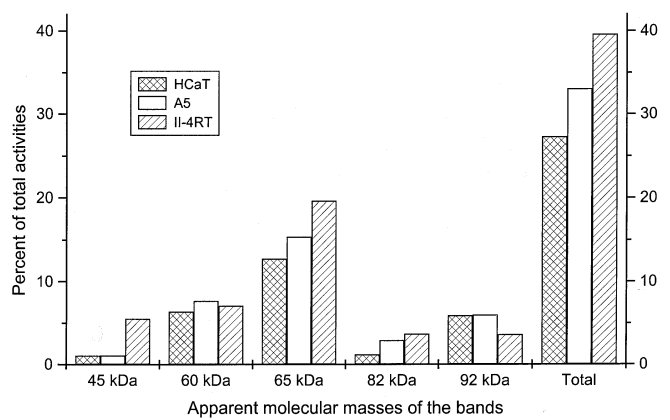

Fig. 3 Densitometric Evaluation of Zymograms of Conditioned Media.

Two zymograms were prepared to which equal amounts of protein from conditioned media from two different cell culture experiments $(15 \mu \mathrm{g} / \mathrm{lane})$ of the three keratinocyte cell lines had been applied. The intensities of the lysis zones were evaluated densitometrically. The total intensity of all lysis zones of each gel was set to $100 \%$ and the percentage contributed by each band calculated. The bars represent the mean values.
MMP - 2 and MMP-2 since the band patterns were virtually identical to that of Figure 2 and, in addition, the lysis zones were identified by the MMP-2 control in similar experiments. The total activity of each zymogram, as represent-

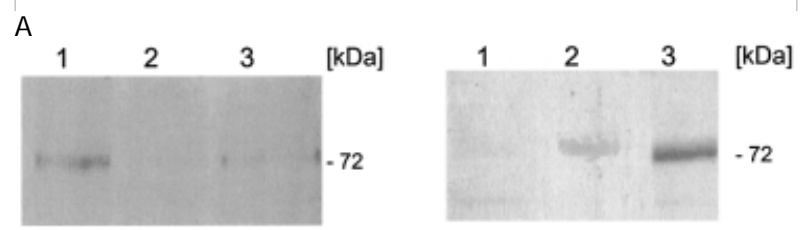

B
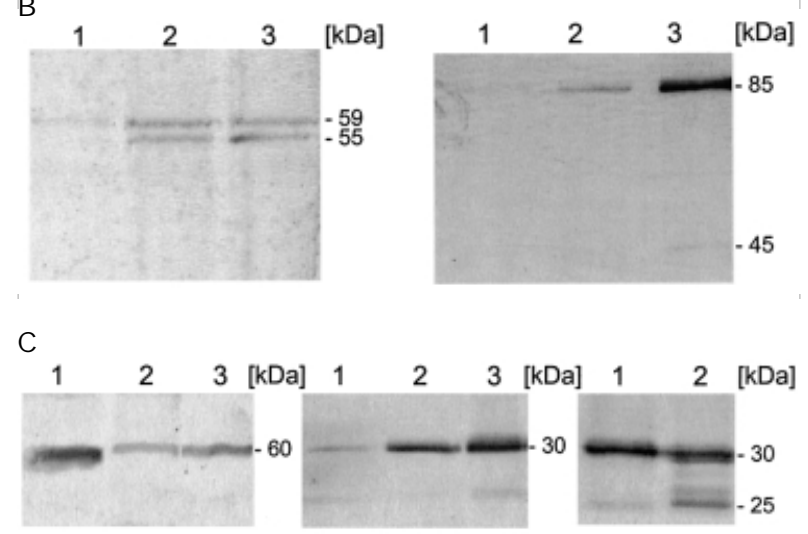

D
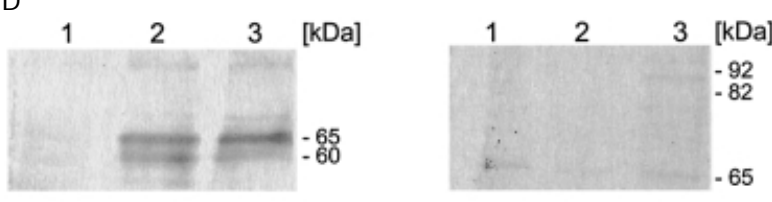

E
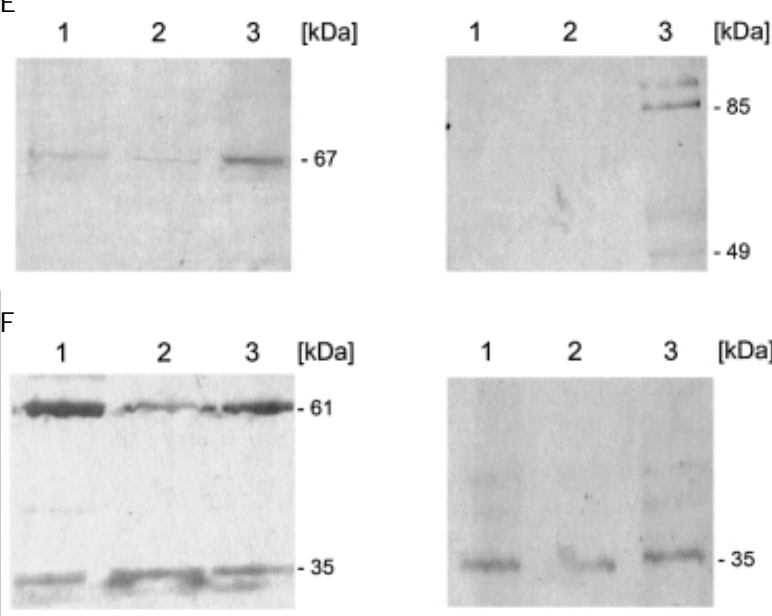

Fig. 4 Western B lot Analyses of Cell Extracts and Serum-Free Conditioned Media of $\mathrm{HaCaT}, \mathrm{A} 5$ and II-4RT Cells Using Specific Antibodies Against M MP-2, -3, -7, -9, -10 and - 11 .

(A) MMP-2; (B) MMP-3; (C) MMP-7; (D) MMP-9; (E) MMP-10; (F) MMP-11.

Western blots were prepared by applying equal amounts of protein per lane ( $60 \mu \mathrm{g}$ of extracts, $15 \mu \mathrm{g}$ of media). The first blot in each one of the panels A-F shows the results of cell extracts, and the second those of conditioned media. Lanes 1, 2, 3, samples from HaCaT, A5 and II-4RT cells, respectively. The third blot of panel C contains conditioned media of II-4RT cells before (lane 1 ) and after (lane 2) treatment with APMA. 
Table 3 Results of Western Blot Analyses.

\begin{tabular}{|c|c|c|c|c|c|c|c|}
\hline & & & extra & & & ditione & media \\
\hline & & $\mathrm{HaCaT}$ & A5 & II-4RT & HaCaT & A5 & II-4RT \\
\hline Pro-MMP-2 & & + & $(+)$ & $-/(+)$ & $-/(+)$ & + & ++ \\
\hline Pro-MMP-3 & two forms & $(+)$ & + & + & - & - & - \\
\hline MMP-3 & monomer & - & - & - & - & - & $(+)$ \\
\hline & dimer & - & - & - & - & + & ++ \\
\hline Pro-MMP-7 & dimer & ++ & + & + & - & - & - \\
\hline & monomer & - & - & - & $(+)$ & + & ++ \\
\hline Pro-MMP-9 & & - & - & - & - & - & $(+)$ \\
\hline MMP-9 & truncated & $(+)$ & + & + & $-/(+)$ & $-/(+)$ & $(+)$ \\
\hline Pro-MMP-10 & & $(+)$ & $(+)$ & + & - & - & - \\
\hline MMP-10 & intermediate & - & - & - & - & - & + \\
\hline & dimer & - & - & - & - & - & + \\
\hline Pro-MMP-11 & & ++ & ++ & ++ & - & - & - \\
\hline MMP-11 & truncated & + & + & + & + & + & + \\
\hline
\end{tabular}

Symbols: -, negative; $-/(+)$, negative or weakly positive; $(+)$, weakly positive; + , positive; ++ , strongly positive.

ed by the sum of the intensities of all lysis zones on the gel, was set to $100 \%$ and the percentage contributed by each band calculated. The evaluation of the results is shown in Figure 3. The intensities of all lysis zones, except those of active MMP-2 $(60 \mathrm{kDa})$ and pro-MMP-9 $(92 \mathrm{kDa})$, were highest for media of the malignant II-4RT cells, second highest for those of benign A5 cells and lowest for those of the nontumorigenic $\mathrm{HaCaT}$ cells. Consistently, also the total gelatinolytic activities (sum of all band intensities of each cell line) increased in the same order.

\section{Western B lot Analysis}

In order to identify individual MMPs directly and to get semi-quantitative information, extracts and conditioned media of the three cell lines were analyzed for immunoreactive MMP $-2,-3,-7,-9,-10$ and -11 by Western blot analysis. The antibodies used are well characterized and highly specific (Lichtinghagen et al., 1995); therefore, the bands detected undoubtedly represent the respective MMPs, even though the positions of the bands were not always in agreement with the known molecular masses of the MMPs.

MMP-2 In extracts of all three cell lines MMP-2 was detected as a faint band of pro-MMP-2 (72 kDa) that was strongest in $\mathrm{HaCaT}$ extracts. In contrast, the $72 \mathrm{kDa}$ band was not found in blots of conditioned media of $\mathrm{HaCaT}$ cells; however, in agreement with the zymography results, it was present in those of $A 5$ and several times as intensive in those of II-4RT (Figure 4A, Table 3).

MMP-3 Bands of MMP-3 were not or hardly visible in Western blots of $\mathrm{HaCaT}$ extracts (Figure $4 \mathrm{~B}$ ). In extracts of $A 5$ and II-4RT cells two bands at 59 and $55 \mathrm{kDa}$, corresponding to pro-MMP-3 and its glycosylated form ( Na- gase, 1995), were observed. In conditioned media of $\mathrm{HaCaT}$ cells no or very weak signals of MMP-3 appeared, whereas in those of $\mathrm{A} 5 \mathrm{a}$ band at $85 \mathrm{kDa}$ and in those of II- $4 \mathrm{RT}$ cells bands at $45 \mathrm{kDa}$ (active intermediate; Nagase, 1995 ) and $85 \mathrm{kDa}$ were detected (Figure 4B, Table 3). The $85 \mathrm{kDa}$ band, probably representing the dimer of active intermediate, was highly intensive in blots of II-4RT media. No band of the mature active form of M MP-3 $(28 \mathrm{kDa})$ was visible in any of the media.

MMP-7 Immunoreactive MMP-7 was detected in extracts of all three cell lines as a $60 \mathrm{kDa}$ band (dimer of proform and/or active MMP-7; F. Woessner, personal communication); the signal was strongest in $\mathrm{HaCaT}$ extracts (Figure 4C, Table 3). Examination of the cell culture supernatants showed that $\mathrm{HaCaT}$ secreted only low amounts of MMP-7, since only a faint band of inactive MMP-7 at $30 \mathrm{kDa}$ was visible. Media of A5 and II-4RT cells, for which only low amounts of M MP- 7 had been detected intracellularly, contained high amounts of inactive MMP-7. After activation with APMA an additional band of active M MP-7 appeared at $25 \mathrm{kDa}$ (Figure 4C, Table 3). In media of II-4RT cells a band of $49 \mathrm{kDa}$ was present that was identified as resulting from some degree of crossreactivity of the MMP-7 antibody with MMP-1 (data not shown).

MMP-9 Two rather faint bands of MMP-9 at about 65 $\mathrm{kDa}$ and $60 \mathrm{kDa}$, corresponding to active forms of MMP-9, were present on blots of $A 5$ and II-4RT extracts while no or very faint bands were detected on those of $\mathrm{HaCaT}$. In conditioned media of all cell lines no or very weak bands at $65 \mathrm{kDa}$ were visible; media of II-4RT cells occasionally showed very faint unknown bands at 92 and $82 \mathrm{kDa}$ and at lower molecular masses. The latter may be due to immunoreactive degradation products (Figure 4D, Table 3). 
MMP-10 MMP-10 was detected in extracts of all cell lines as proenzyme. The characteristic $67 \mathrm{kDa}$ band was strong in II-4RT cells and was of low, about equal intensity in $\mathrm{HaC}$ aT and A5 cells. Only in conditioned media of II-4RT cells an $85 \mathrm{kDa}$ band of active dimer and a $49 \mathrm{kDa}$ band of active intermediate were observed (Figure 4E, Table 3).

MMP-11 Two bands of MMP-11 were found in cell extracts, one of $61 \mathrm{kDa}$ representing the glycosylated proenzyme and one of $35 \mathrm{kDa}$, probably representing a $\mathrm{C}$-terminal truncation product of the active enzyme (Pei and Weiss, 1998). In conditioned media only the $35 \mathrm{kDa}$ band was detected that was of equal intensity in media of all three cell lines (Figure 4F, Table 3).

\section{Discussion}

HaCaT, a spontaneously immortalized keratinocyte cell line originating from human adult skin, exhibits normal differentiation and is nontumorigenic as demonstrated by implantation into athymic nude mice (Boukamp et al., 1988). When this cell line was transfected with the c-Haras oncogene on a plasmid construct (Boukamp et al., 1990), three classes of clones with stably integrated Haras could be selected that differed in respect to in vivo tumorigenicity: class I clones were nontumorigenic like the parental $\mathrm{HaCaT}$, they formed small, regressing nodules when injected into athymic mice; class II clones formed benign, noninvasive cysts, and class III clones produced highly differentiated, locally invasive squamous cell carcinomas. Expression of the gene product 21 of Ha-ras was detected only in class II and III cells, at highly variable levels (Boukamp et al., 1990), and did not show a correlation to the degree of tumorigenicity. Control experiments with $\mathrm{HaCaT}$ cells and clones transfected with vector without the Ha-ras insert showed that all of these cell clones were nontumorigenic like class I clones.

A combination of $\mathrm{HaCaT}$, class II and class III cells should provide an excellent model for studying correlations between tumorigenicity and expression of proteinases as well as other factors involved in the malignant transformation of cells. Here we investigated whether the different in vivo growth potential of $\mathrm{HaCaT}, \mathrm{A} 5$ (class II) and II-4RT (class III) cells is reflected in the constitutive expression of MMP $-2,-3,-7,-9,-10$ and -11 .

RT-PCR studies showed that all three cell lines express the mRNAs of the six MMPs. Due to their nonquantitative nature these results provide no evidence on whether the expression levels of the MMP MRNAs differ in the three cell lines; however, the results indicate that all three cell lines are capable of synthesizing the corresponding enzymes. Their actual production in the cells was unequivocally demonstrated by gelatin zymographic and Western blot analyses.

By gelatin zymography M MP-2 and -9 can be detected with high sensitivity. When this method was employed to examine the presence of these two enzymes within the cells, in extracts of all three cell lines main bands of $72 \mathrm{kDa}$ (pro-MMP-2) and $65 \mathrm{kDa}$ (activated forms of MMP-2) were observed. The presence of active MMP-2 in the extracts does probably not reflect intracellularly active enzyme, but is rather due to partial activation during sample preparation. In some experiments (like this shown in Figure 2) the intensities of the bands increased with tumorigenicity of the cell clones.

Zymographic analysis of conditioned media showed that MM P-2 and - 9 were present both as the pro- and active forms. The quantitative densitometric evaluation of zymograms of conditioned media clearly demonstrated that secretion of gelatinolytic activities correlated with the degree of in vivo tumorigenicity (Figure 3 ). This was true for both the total activity and the single bands, except for the $60 \mathrm{kDa}$ (active MMP-2) and the $92 \mathrm{kDa}$ (proMMP-9) lysis zones. In all three cell lines most of the gelatinolytic activity was due to MMP-2 (about 2.7-fold higher than that of MMP-9). On Western blots virtually no MMP-9 was found in the media of the three cell lines due to the lower sensitivity compared to gelatin zymography (Figure 4D). Only the pro-form of M MP- 2 was detectable (Figure 4A): in media of $\mathrm{HaCaT}$ generally no bands and in those of A5 cells only faint bands were visible, whereas in II-4RT media a rather strong band appeared, being several fold more intensive than that of A5 media. In contrast, the zymographic analyses showed for the three cell lines much lower differences in the intensities of the M MP-2 lysis zones (Figure 3). We assume that the degree of partial activation of proMMP-2 taking place during the renaturation step of the zymographic process (Woessner, 1995) is dependent on the amount of pro-MMP-2 applied onto the gel; therefore, proMMP-2 activation was much less complete in our experiments for the II-4RT than for the $\mathrm{HaCaT}$ and $\mathrm{A} 5$ samples, resulting in an underestimation of the MMP-2 amount. Thus, the actual relative concentrations of pro-MMP- 2 in the media of the three cell lines are probably better represented by the immunoblot than by the zymography results.

Taken together, zymography and Western blot results (Figure 3, Table 3) clearly show that constitutive production and secretion of M MP-2 and - 9 increase from the nontumorigenic to the benign and the malignant tumorigenic phenotype of the cells.

Recently, Borchers et al. (1994) investigated II- 4 cells (the corresponding II-4RT cells used in this study differ from II-4 in that they were re-established in culture after one in vivo passage of II- 4 cells in athymic mice; Boukamp et al., 1990) for the induction of MMP-2 and MMP-9 expression when kept in monolayer coculture with human foreskin fibroblasts. They also studied $\mathrm{HaCaT}$ and II-4RT cells in an in vitro three-dimensional model, in which the keratinocytes were grown on a collagen gel embedded with human dermal fibroblasts (B orchers et al., 1997). Except that, in contrast to our results, they found no MMP-9 expression by II- 4 cells in the monolayer coculture (even though in the three-dimensional system), their results agree with ours in that M M P-9 expression is higher in II-4 
than in $\mathrm{HaC}$ aT cells. Interestingly, coculture of II-4, but not of $\mathrm{HaCaT}$, with fibroblasts caused an increase in MMP-9 production; however, it was not established whether II-4 cells or fibroblast were responsible for the higher MMP-9 expression. For MMP-2 production no such stimulating effect of cocultured fibroblasts was observed.

As a whole, the results of Borchers et al. $(1994,1997)$ and those presented in this study indicate that in the investigated model system MMP-9 is an example of a proteinase whose constitutive expression is increased in the higher tumorigenic cell line, but an additional increase, whether tumor or stroma cell-induced, is caused by interaction with the stroma. On the other hand, MMP-2 is a representative of those proteinases whose constitutive expression is enhanced in the tumorigenic cells, and tumor-stroma interaction does notresult in further upregulation.

Meade-Tollin et al. (1998) reported on the expression of MMP - 2, -7 and -9 in $\mathrm{HaC}$ aT and the cell lines A- 4 of class I (see above; no corresponding clone was included in the present study), I- 7 of class II (like A- 5 of our study), and the class III clone II-4 (see above). By Northern blot analysis they detected expression of MMP-2 and MMP-7 mRNAs in the cells. Like Borchers et al. (1994), but in contrast to our findings, they did not observe any MMP-9 mRNA expression; however, all of the cell lines secreted the M M P-9 protein.

When Meade-Tollin et al. (1998) investigated secretion into the medium of MMP-2 and -9 by zymography and of MMP -7 by Western blotting, they found that, in comparison to the non-tumorigenic $\mathrm{HaCaT}$ and A-4 cells, secretion of MMP-7 and - 9 was equally enhanced in the two tumorigenic variants I-7 and II-4. Thus, contrasting our results which clearly demonstrate that MMP-2, -7 and -9 secretion increases with the degree of tumorigenicity, they did not observe a difference in the secretion of these MMPs between the benign tumorigenic I-7 and the malignant II- 4 cells. This discrepancy is probably due to the fact that Meade-Tollin et al. did neither perform Western blot analyses of MMP-2 and - 9 nor densitometric evaluation of zymograms, and thus differences in MMP secretion between their two tumorigenic cell clones may have been overlooked

It is interesting to note that our clone A-5 synthesizes significantly less $\mathrm{p} 21$, the gene product of $\mathrm{Ha}$-ras, than the corresponding I-7 clone (Boukamp et al., 1990) used by Meade-Tollin et al. (1998). But in spite of this lower p21 expression, A- 5 shows higher expression of MMP-2, -7 and - 9 than $\mathrm{HaCaT}$, just like the $\mathrm{I}-7$ clone. Similarly, MeadeTollin et al. reported that the Ha-ras transfected A-4 cells, although they do not produce $\mathrm{p} 21$, secrete more MMP-2 than $\mathrm{HaCaT}$. This may indicate that the ability for enhanced synthesis and secretion of MMP-2, -7 and -9 (and also of M MP-3 and - 10, cf. below) was acquired as a result of transfection with the Ha-ras oncogene, but the actual expression level of p21 is not important for regulating MMP - 2, -7 and -9 production. In contrast, a direct involvement of ras oncogenes in the induction and regulation of proteinase expression has been shown recently (Zhang and Schultz, 1992; Silberman et al., 1997) for the proteinases urokinase plasminogen activator (UPA) and cathepsin L by transformation of NIH 3T3 fibroblasts with EJ-ras, chimeric EJ/vHa-ras and yeast RAS1Leu sequences, respectively.

Pyke et al. (1992) studied the expression of the mRNAs of MMP-2 and -9 in human skin cancer by in situ hybridization. In all nine squamous cell carcinomas investigated MMP-2 mRNA was present, localized in many fibroblasts especially in the stroma adjacent to the invasive tumor nodules, but not in the malignant cells. MMP-9 mRNA was found in malignant cells of six out of the nine carcinomas at or near the tumor-stroma interface. The absence of MMP-2 mRNA in malignant squamous cells contrasts our results. Possible explanations are the lower sensitivity of in situ hybrid ization as compared to N orthern and RT-PCR analyses and differences in the type of malignant transformation of the cells. Several cases of such differences in the phenotype of malignant cells originating from an identical parental cell type have been reported, and are reflected for example already in the results of Pyke et al., since, in the case of MMP-9, they found mRNA expression in malignant cells of only one third of the squamous cell carcinomas investigated.

MMP-3 and -10 (stromelysin-1 and -2) have previously been localized in cancerous tissues both in tumor and in stromal cells (Polette et al., 1991; Wright et al., 1994; Werb et al., 1996; Lochter et al., 1997). In the three keratinocyte cell lines investigated here, Western blot analysis of extracts showed that stromelysin- 1 and -2 are constitutively expressed by all three cell lines (Figures $4 \mathrm{~B}$ and $4 \mathrm{E}$; Table 3). Examination of conditioned media revealed distinct differences in the secretion of the two enzymes (Figures 4B and $4 \mathrm{E}$; Table 3): MMP-3 was not detectable in media of the non-tumorigenic $\mathrm{HaCaT}$ cells, but signals of moderate and high intensities were obtained with media of A-5 and II-4RT, and M M P-10 was detected only in media of the malignant II-4RT cells. Thus, like MMP-9 (see above), in the model of the three keratinocyte cell lines MMP- 3 and - 10 are proteinases which are expressed and secreted by the tumorigenic cells at increased levels, but, as the above mentioned reports indicate, in cancerous tissues the sole or additional production by stromal cells or/and upregulation by them is also possible.

MMP-11 (stromelysin-3) has, with few exceptions, consistently been found expressed exclusively in fibroblasts adjacent to cancer cells (Muller et al., 1993; Rouyer et al., 1994; Porte et al., 1995; Munck-Wikland et al., 1998; Tetu et al., 1998). Unexpectedly, in our studies MMP-11 was detected in extracts of the three cell lines, and it was secreted into the media at about equal levels by all cells (Figure 4F; Table 3). To ourknowledge, such an expression of stromelysin- 3 by epithelial cells has been reported previously only by Bolon et al. $(1996,1997)$ in precancerous bronchial lesions and lung carcinoma and by von Marschall et al. (1998), who detected stromelysin-3 protein in ep ithelial tumor cells of six out of 21 human pancre- 
atic carcinomas, and both mRNA and protein in all of the five investigated pancreatic carcinoma cell lines. In the light of these and our results the generally accepted concept of the exclusive production of stromelysin-3 by stromal cells has to be revised and other tumor types and cancer cell lines will have to be (re-)examined for stromelysin-3 expression. It will be interesting to investigate whether MMP-11 expression and secretion by the keratinocyte cell lines is upregulated in coculture with stromal cells and whether there is a correlation of such an upregulation with the tumorigenic phenotype.

The intracellular MMP pools of the keratinocyte cell lines have not been examined by other investigators. Our Western blot analyses of cell extracts show that there exist significant differences between the three cell variants not only in the constitutive secretion of MMPs, but also in the intracellular pool, although no consistent direct correlation between the intracellular M MP content and the tumorigenicity was observed: signals of MMP -2 and -7 were most intensive in extracts of $\mathrm{HaCaT}$; those of M MP-10 in II4RT extracts, and the bands of MMP-3 and -9 were about equally intensive in extracts of the two tumorigenic variants, but stronger than in those of $\mathrm{HaCaT}$. In contrast, the secretion of all five M M Ps was highest in II-4RT cells (Table 3). On the one hand, it is not surprising that intracellular MMP concentrations are not directly parallel to the secretion levels of the respective cell lines, considering that a constantly enhanced secretion of the various M MPs must be due to a constant upregulation of their synthesis and, thus, does not have to be reflected in the intracellular content. On the other hand, the differences in the cellular concentrations of certain MMPs observed in the three cell lines indicate special functions of the cellular pool. For example, in regard to the functional significance of the increased intracellular concentration of MMP-3, -9 and -10 in one or both of the two tumorigenic variants, one might speculate that these proteinases are kept 'in stock' for an immediate secretory response upon induction by mediators such as cytokines. However, the validity of this assumption will have to be examined by detailed stimulation studies.

The contribution of proteinases in neoplastic processes was and still is mainly seen in the degradation of extracellular matrices, which is necessary for the tumor cells to invade the surrounding tissue as well as for intra- and extravasation. Thus, from a simplistic point of view one would not expect an enhanced production of MMPs by the noninvasive tumorigenic A5 cells, as they do not 'need' to degrade extracellular matrix when proliferating encapsulated in cysts. However, recent studies indicate (Chambers and Matrisian, 1997; Noël et al., 1997) that M M Ps and other proteinases have additional functions in sustaining and modulating tumor growth, for example by generating growth factors. It is conceivable that the role of increased MMP expression by the cyst-forming, benign tumorigenic A5 cells is to fulfill especially this purpose.

In conclusion, we have selected a model system of three keratinocyte cell lines of different tumorigenicities for studies on the differential expression of six MMPs. The reason for choosing especially these cells as a model was that the two differently tumorigenic cell lines have been derived from the same parental $\mathrm{HaCaT}$ cells and, therefore, the three cell lines are closely related. In addition, each of the cell lines is of clonal origin and the respective in vivo tumorigenic phenotype is well characterized. Our results modify and largely extend previous findings of other groups, who investigated in related cell lines mRNA expression and secretion into the media, but of only up to three MMPs. We have demonstrated that MMP-2, $-3,-7$, -9 and -10 are differently produced, stored and secreted by the three cell lines, and that the secretion increases in correlation with the tumorigenicity. In the in vivo situation presumably not solely this increased constitutive production of five MMPs will be responsible for the increased tumorigenicity, but multifold additional parameters as well as tumor-stroma interactions will also play significant roles. As a next step to clarify this aspect coculture studies with fibroblasts will be performed.

Different from the current view that stromelysin-3 (MMP-11) is exclusively expressed by stromal fibroblasts and not by tumor cells, we found that all three keratinocyte cell lines synthesize, store and secrete this enzyme at equal levels; thus, re-examination of the previous results on M MP-11 expression in cancer tissues and cell lines will be necessary.

Our study demonstrates that the three cell lines represent an excellent model for investigating correlations between the degree of in vivo tumorigenicity of cells and constitutive MMP expression as well as its regulation. Subsequent studies in cocultures of the keratinocyte cell lines with stromal cells will provide information on the additional regulatory influence of tumor-stroma interactions. We conclude that the model system will be equally valuable in studies on the regulation of further proteinases and other parameters associated with tumor progression.

\section{Materials and Methods}

\section{Cell Lines and $\mathrm{C}$ ulture Conditions}

The cell lines investigated were $\mathrm{HaCaT}, \mathrm{A} 5$ and II-4RT. HaCaT is a spontaneously immortalized human keratinocyte cell line (Boukamp et al., 1988), A5 and II-4RT are cell lines of different tumorigenicities (cf. Discussion) derived from $\mathrm{HaC}$ aT by transfection with the activated c-Ha-ras (EJ ) oncogene (Boukamp et al., 1990). The passages used were between 32 and 50 for HaCaT, between 39 and 55 for A5, and between 12 and 45 for II-4RT.

Culture Conditions Cells were cultured at $37^{\circ} \mathrm{C}$ in a humidified atmosphere of $5 \% \quad \mathrm{CO}_{2}$ and $95 \%$ air. Dulbecco's modified Eagle's medium Low Glucose $(1 \mathrm{~g} / \mathrm{l})$, supplemented with 0.35 $\mathrm{mg} / \mathrm{ml} \mathrm{L}$-glutamine and $0.05 \mathrm{mg} / \mathrm{ml}$ gentamycin sulfate, was the basal medium for $\mathrm{HaCaT}$. For A5 and II-4RT cells gentamycine sulfate was substituted by $0.2 \mathrm{mg} / \mathrm{ml}$ geneticine. Cultures were maintained in the basal medium supplemented with $10 \%$ heatinactivated fetal calf serum. The medium was changed every three days. For subcultures cells were harvested after brief treatment with $0.1 \%$ trypsin/EDTA solution and seeded at a dilution of $1: 10$. 
Preparation of Serum-Free Conditioned Medium Cells were grown to about $90 \%$ confluence in $75 \mathrm{~cm}^{2}$ plastic culture flasks containing $10 \mathrm{ml}$ medium. The cultures were rinsed three times with $\mathrm{Ca}^{2+}$ - and $\mathrm{Mg}^{2+}$-free PBS and then $10 \mathrm{ml}$ of serum-free basal medium was added. After two days, the conditioned medium was collected and concentrated by ultrafiltration (exclusion limit $10 \mathrm{kDa})$. The concentrated conditioned medium was stored at $-20^{\circ} \mathrm{C}$

Harvesting of Cells Cells grown in serum-containing medium were washed three times with $5 \mathrm{ml}$ PBS and harvested at confluence by scraping off the cell layer in $5 \mathrm{mIPBS}$. The cell suspension of each flask was collected into a $50 \mathrm{ml}$ tube and washed twice with $50 \mathrm{ml}$ PBS by centrifugating (10 $\mathrm{min}$ at $300 \mathrm{~g}$ ). Aliquots of $1.5-1.7 \times 10^{7}$ cells were stored at $-70^{\circ} \mathrm{C}$.

Preparation of Cell Extracts Fifty $\mu$ of lysis buffer $(10 \mathrm{~mm}$ $\mathrm{Na}_{3} \mathrm{PO}_{4} ; 0.4 \mathrm{M} \mathrm{NaCl} ; 0.2 \%$ Triton $\mathrm{X}-100$ ) were added to an aliquot of frozen cells. The mixture was sonified and after centrifugation for $14 \mathrm{~min}$ at $15000 \mathrm{~g}$ the supernatant containing the soluble proteins was collected and either used immediately or stored at - $20{ }^{\circ} \mathrm{C}$. These extracts were analyzed by Western blot analysis and zymography.

Determination of Protein Concentration Protein concentrations were determined by the bicinchoninic acid protein assay method (Pierce, Oud-Beijerland, Netherlands) using bovine serum albumin as a standard.

\section{Zymography}

ForSDS-PAGE slab gels $(80 \mathrm{~mm} \times 80 \mathrm{~mm} \times 0.75 \mathrm{~mm})$ containing $12 \%$ acrylamide and $1 \mathrm{mg} / \mathrm{ml}$ of gelatin were prepared (Heussen and Dowdle, 1980), and electrophoresis was carried out under nonreducing conditions. Renaturation of the proteins was achieved by incubating the gels in $25 \mathrm{~g} / \mathrm{I}$ Triton X-100 at room temperature for $2 \times 10 \mathrm{~min}$. Subsequently the gels were incubated in $50 \mathrm{~mm}$ Tris- $\mathrm{HCl}, \mathrm{pH} 7.5$ containing $0.2 \mathrm{M} \mathrm{NaCl}, 0.02 \%$ Brij35 and $10 \mathrm{~mm} \mathrm{CaCl}$ at $37{ }^{\circ} \mathrm{C}$ for $18 \mathrm{~h}$. For inhibition studies one of the following inhibitors was added to all solutions: $30 \mu \mathrm{M} E 64,10 \mu \mathrm{m}$ leupeptin, 1 mm PMSF, 2 mm EDTA, or 1 mm o-phenanthroline. The molecular weight markers used were rabbit muscle phosphorylase $b$, bovine serum albumin, ovalbumin, bovine carbonic anhydrase, soybean trypsin inhibitor, hen egg lysozyme (Bio-Rad prestained markers, low range). After staining the gels with Coomassie Brilliant Blue R-250 and destaining, zones of proteolytic activities became visible as transparent bands in the stained gel.

In order to activate zymogens of MMP-2 and -9 , aliquots of serum-free conditioned media of NB- 4 cells (M MP- 2 control), human foreskin fibroblasts (M M P-9 control) and II-4RT were activated by treatment with 2 mM APMA (4-aminophenylmercuric acetate) at $37^{\circ} \mathrm{C}$ for $2 \mathrm{~h}$ before electrophoresis. Since the activation was not complete, both the proenzymes and the activated forms were detectable in the zymograms (Figure 2) or Western blots (Figure 4F).

For comparing the proteolytic activities in conditioned media zymograms of two gels were prepared to which $15 \mu \mathrm{g}$ protein per lane from conditioned media of each cell line (two different cell culture experiments) had been applied. The zymograms were scanned and the intensities of the transparent zones determined using the software Image Master (Pharmacia). The total intensity of all lysis zones in each zymogram was set to $100 \%$ and the percentage contributed by each band was calculated.

\section{Reverse Transcription and Polymerase Chain Reaction}

RNA Extraction Total RNA was extracted from cells according to the method of Chomczynski and Sacchi (1987) using TRI
Reagent (Sigma, Deisenhofen, Germany). Total RNA was quantified at 260/280 nm. Aliquots were stored in DEPC-treated water or $0.1 \mathrm{M}$ sodium acetate in ethanol at $-80^{\circ} \mathrm{C}$.

Primer Design and Synthesis Primers (Table 1) were designed using DNA sequences stored in the GenBank database: MMP-2 (accession numbers M55587 J 05471; M55593 J 05471), MMP-3 (accession number U78045), MMP-7 (accession numbers L22519; L22524), MMP-9 (accession numbers M68345 M68351), MMP-10 (accession numbers X07820 Y00728), MMP11 (accession number X57766). The primers were synthesized by MWG (Ebersberg, Germany) or TopLab (Munich, Germany).

Reverse Transcription cDNAs were synthesized from $1 \mu \mathrm{g}$ total RNA using a First-Strand cDNA Synthesis Kit (Pharmacia Biotech, Freiburg, Germany). The reactions were carried out following the manufacturer's instructions using the specific outer reverse primers (Table 1 ).

Semi-Nested PCR The first PCR with forward and outer reverse primers was carried out with $1 / 10$ of the synthesized cDNA in a reaction mixture (total volume $25 \mu \mathrm{l}$ )containing $10 \mathrm{pmol}$ of each primer, $40 \mathrm{nmol}$ dNTP, $1 \mathrm{U}$ Goldstar Taq-polymerase (Eurogentec) and $6 \mathrm{~mm} \mathrm{MgCl}, 20 \mathrm{~mm}\left(\mathrm{NH}_{4}\right)_{2} \mathrm{SO}_{4}, 75 \mathrm{~mm}$ Tris/ $\mathrm{HCl}$, $0.1 \mathrm{~g} /$ ITween-20, pH 9.0, or $1 \mathrm{U}$ PANS cript polymerase (PAN-Systems) and $6 \mathrm{~mm} \mathrm{MgCl}, 16 \mathrm{~mm}\left(\mathrm{NH}_{4}\right)_{2} \mathrm{SO}_{4}, 50 \mathrm{~mm}$ Tris/ $\mathrm{HCl}, 0.1 \mathrm{~g} / \mathrm{l}$ Tween-20, pH 8.8. PCR conditions were $5 \mathrm{~min}$ incubation at $94{ }^{\circ} \mathrm{C}$, followed by 25 cycles of $30 \mathrm{~s}$ at $56^{\circ} \mathrm{C}, 1 \mathrm{~min}$ at $72{ }^{\circ} \mathrm{C}, 30 \mathrm{~s}$ at $94^{\circ} \mathrm{C}$, and a final cycle of $30 \mathrm{~s}$ at $56^{\circ} \mathrm{C}, 5 \mathrm{~min}$ at $72^{\circ} \mathrm{C}$. The second $P C R$ with forward and inner reverse primer was carried out using $1 \mu \mathrm{l}$ of the first PCR mixture, a total volume of $50 \mu \mathrm{l}$ and 35 cycles. Concentrations of all reagents and cycle profiles were as in the first PCR. Negative controls were carried out in the same manner but without template.

Characterization of RT-PCR Products PCR products were characterized by size determination and restriction fragment analysis. For restriction analysis the endonucleases given in Table 2 were used. Eight $\mu$ of the reaction mixture of the second PCR was added to a mixture of $1 \mathrm{U}$ restriction endonuclease and $2 \mu$ $10 \times$ reaction buffer; deionized water was added to a final volume of $20 \mu$ l. The mixture was incubated at $37^{\circ} \mathrm{C}$ for $1 \mathrm{~h}$. PCR products and restriction fragments were subjected to polyacrylamide gel electrophoresis in $14 \%$ gels containing $10 \%$ glycerol and their sizes determined by comparison with DNA length standards.

\section{Immunoblotting}

Sixty $\mu \mathrm{g}$ protein of cell extract and $15 \mu \mathrm{g}$ protein of conditioned media (for M M P - 7 also after activation with APMA, cf. section on zymography) were subjected to SDS-PAGE in $10 \%$ polyacrylamide slab gels under nonreducing conditions. Electrotransfer to a nitrocellulose membrane was performed with $39 \mathrm{~mm}$ glycine, $48 \mathrm{~mm}$ Tris-base, $370 \mathrm{mg} / \mathrm{l} \mathrm{SDS}$ and $20 \%$ (v/v) methanol at 125 $\mathrm{mA} / \mathrm{cm}^{2}$ for $2 \mathrm{~h}$. The membranes were incubated overnight at $4{ }^{\circ} \mathrm{C}$ in TTBS (50 mm Tris-base, 150 mm NaCl, 1 g/l Tween-20, pH 7.5) containing $50 \mathrm{~g} / \mathrm{l}$ low fat dry milk powder. All following steps were carried out at room temperature. The membranes were rinsed three times for 10 min with TTBS and incubated for $2 \mathrm{~h}$ in a dilution of specific polyclonal rabbitantiserum (Lichtinghagen etal., 1995) in TTBS containing $10 \mathrm{~g} / \mathrm{l}$ low fat dry milk powder. The dilutions used were 1:500 for anti-MMP-2, -9 and -10, 1:750 for anti-M MP3 and -7 , and 1:500 and 1:750 for M MP-11 in media and extracts, respectively. The membranes were washed three times for $10 \mathrm{~min}$ in TTBS and incubated for $1 \mathrm{~h}$ with a 1:1000 dilution of porcine anti-rabbit immunoglobulin $\mathrm{G}$ alkaline phosphatate conjugate (DAKO) in TTBS containing $10 \mathrm{~g} / \mathrm{l}$ low fat dry milk powder. After rinsing twice with TTBS and once with $50 \mathrm{~mm}$ Tris-base, $150 \mathrm{~mm}$ $\mathrm{NaCl}, \mathrm{pH} 7.5$, the membrane was incubated with 5-bromo-4- 
chloro-3-indolyl phosphate/nitro blue tetrazolium (165 and 330 $\mathrm{mg} / \mathrm{l}$, respectively) to visualize bands of alkaline phosphatase activity. In immunoblots of MMP-3, M M P-7 and MMP-10 we detected strong bands at positions that correspond to about twice the molecular mass of the MMP or its pro-form (Table 3, Figure $4 B, C, E)$ which we interpret as dimers. Such dimerization is occasionally observed with MMPs even under reducing conditions (F. Woessner, personal communication).

\section{References}

Bernhard, E.J ., Gruber, S.B., and Muschel, R.J . (1994). Direct evidence linking expression of matrix metalloproteinase 9 (92-kDa gelatinase/collagenase) to the metastatic phenotype in transformed rat embryo cells. Proc. Natl. Acad. Sci. USA 91, 4293 - 4297.

Bolon, I., B rambilla, E., Vandenbunder, B., Robert, C., Lantuejoul, S., and Brambilla, C. (1996). Changes in the expression of matrix proteases and of the transcription factor C-Ets-1 during progression of precancerous bronchial lesions. Lab. Invest. 75, $1-13$.

Bolon, I., Devouassoux, M., Robert, C., Moro, D., Brambilla, C., and Brambilla, E. (1997). Expression of urokinase-type plasminogen activator, stromelysin 1 , stromelysin 3 , and matrilysin genes in lung carcinomas. Am. J . Pathol. 150, 1619 - 1629.

Borchers, A.H., Powell, M.B., Fusenig, N.E., and Bowden, G.T. (1994). Paracrine factor and cell-cell contact-mediated induction of protease and c-ets gene expression in malignant keratinocyte/dermal fibroblast cocultures. Exp. Cell. Res. 213, $143-147$.

Borchers, A.H., Steinbauer, H., Schafer, B.S., Kramer, M., Bowden, G.T., and Fusenig, N.E. (1997). Fibroblast-directed expression and localization of 92-kDa type IV collagenase along the tumor-stroma interface in an in vitro three-dimensional model of human squamous cell carcinoma. Mol. Carcinogen. $19,258-266$.

Boukamp, P., Petrussevska, R.T., B reitkreutz, D., Hornung, J . Markham, A., and Fusenig, N.E. (1988). Normal keratinization in a spontaneously immortalized aneuploid human keratinocyte cell line. J. Cell Biol. 106, 761 - 771.

Boukamp, P., Stanbridge, E.J., Foo, D.Y., Cerutti, P.A., and Fusenig, N.E. (1990). C-Ha-ras oncogene expression in immortalized human keratinocytes ( $\mathrm{HaCaT}$ ) alters growth in vivo but lacks correlation with malignancy. Cancer Res. 50, 2840 2847.

Chambers, A.F., and Matrisian, L.M. (1997). Changing views of the role of matrix metalloproteinases in metastasis. J. Nat. Cancer Inst. 89, 1260 - 1270.

Chomczynsky, P., and Sacchi, N. (1987). Single-step method of RNA isolation by acid guanidinium thiocyanate-phenol-chloroform extraction. Anal. Biochem. 162, $156-159$.

Heussen, C., and Dowdle, E.B. (1980). Electrophoretic analysis of plasminogen activators in polyacrylamide gels containing sodium dodecyl sulfate and copolymerized substrates. Anal. Biochem. 102, 196 - 202.

Itoh, T., Tanioka, M., Yoshida, H., Yosioka, T., Nishimoto, H., and Itohara, S. (1998). Reduced angiogenesis and tumor progression in gelatinase A-deficient mice. Cancer Res. 58, 1048 1051.

Karameris, A., Panagou, P., Tsilalis, T., and Bouros, D. (1997). Association of expression of metalloproteinases and their inhibitors with the metastatic potential of squamous-cell lung carcinomas - a molecular and immunohistochemical study. Am. J . Respir. Crit. Care Med. 156, 1930 - 1936.
Khokha, R., Waterhouse, P., Yagel, S., Lala, P.K., Overall, C.M., Norton, G., and Denhardt, D.T. (1989). Antisense RNA-induced reduction in murine TIMP levels confers oncogenicity on Swiss 3 T3 cells. Science 243, $947-950$.

Knox, J.D., Mack, C.F., Powell, W.C., Bowden, G.T., and Nagle, R.B. (1993). Prostate tumor cell invasion: a comparison of orthotopic and ectopic models. Invas. Metast. 13, 325 - 331.

Koop, S., Khokha, R., Schmidt, E.E., MacDonald, I.C., Morris, V.L., Chambers, A.F., and Groom, A.C. (1994). Overexpression of metalloproteinase inhibitor in B16F 10 cells does not affect extravasation but reduces tumor growth. Cancer Res. 54, $4791-4797$.

Liaw, L., and Crawford, H.C. (1999). Functions of the extracellular matrix and matrix degrading proteases during tumor progression. Braz. J. Med. Biol. Res. 32, 805 - 812.

Lichtinghagen, R., Helmbrecht, T., Arndt, B., and Boker, K.H.W. (1995). Expression pattern of matrix metalloproteinases in human liver. Eur. J. Clin. Chem. Clin. Biochem. 33, 65 - 71.

Lochter, A., Srebrow, A., Sympson, C.J ., Terracio, N., Werb, Z., and Bissell, M.J . (1997). Misregulation of stromelysin-1 expression in mouse mammary tumor cells accompanies acquisition of stromelysin-1-dependent invasive properties. J . Biol. Chem. $272,5007-5015$

Masson, R., Lefebvre, O., Noel, A., Fahime, M.E., Chenard, M.P., Wendling, C., Kebersnc, F., LeMeur, M., Dierich, A., Foidart, J .M., Basset, P., and Rio, M.C. (1998). In vivo evidence that the stromelysin- 3 metalloproteinase contributes in a paracrine manner to epithelial cell malignay. J . Cell Biol. 140

Meade-Tollin, L.C., Boukamp, P., Fusenig, N.E., Bowen, C.P.R., Tsang, T.C., and B owden, G.T. (1998). Differential expression of matrix metalloproteinases in activated c-ras $(\mathrm{Ha})$-transfected immortalized human keratinocytes. Brit. J . Cancer 77, 724 730.

Mignatti, P., and Rifkin, D.B. (1993). Biology and biochemistry of proteinases in tumor invasion. Physiol. Rev. 73, 161 - 195.

Morris, V.L., Koop, S., MacDonald, I.C., Schmidt, E.E., Grattan, M., Percy, D., Chambers, A.F., and Groom, A.C. (1994). Mammary carcinoma cell lines of high and low metastatic potential differ not in extravasation but in subsequent migration and growth. Clin. Exp. Metast. 12, 357 - 367.

Muller, D., Wolf, C., Abecassis, J., Millon, R., Engelmann, A., Bronner, G., Rouyer, N., Rio, M.C., Eber, M., Methlin, G. et al. (1993). Increased stromelysin 3 gene expression is associated with increased local invasiveness in head and neck squamous cell carcinomas. Cancer Res. 53, 165 - 169.

Munck-Wikland, E., Heselmeyer, K., Lindholm, J ., Kuylenstierna, R., Auer, G., and Engel, G. (1998). Stromelysin-3 mRNA expression in dysplasias and invasive epithelial cancer of the larynx. Int. J. Oncol. 12, 859 - 864.

Nagase, H. (1995). Stromelysins 1 and 2. Meth. Enzymol. 248, $449-484$.

Noël, A., Gilles, C., Bajou, K., Devy, L., Kebers, F., Lewalle, J .M., Maquoi, E., Munaut, C., Remacle, A., and Foidart, J .M. (1997). Emerging roles for proteinases in cancer. Invas. Metast. 17, $221-239$.

Pei, D., and Weiss, S.J . (1998). Stromelysin 3. In: Handbook of Proteolytic Enzymes, A.J. Barrett, N.D. Rawlings and J.F. Woessner, eds. (London, UK: Academic Press), pp. 11871190.

Polette, M., Clavel, C., Muller, D., Abecassis, J ., Binninger, I., and Birembaut, P. (1991). Detection of mRNAs encoding collagenase land stromelysin 2 in carcinomas of the head and neck by in situ hybridization. Invas. Metast. 11, 76 - 83.

Porte, H., Chastre, E., Prevot, S., Nordlinger, B., Empereur, S., Basset, P., Chambon, P., and Gespach, C. (1995). Neoplastic progression of human colorectal cancer is associated with 
overexpression of the stromelysin-3 and BM-40/SPARC genes. Int. J . Cancer. 64, 70 - 75.

Powell, W.C., Knox, J.D., Navre, M., Grogan, T.M., Kittelson, J ., Nagle, R.B., and B owden, G.T. (1993). Expression of the metalloproteinase matrilysin in DU-145 cells increases their invasive potential in severe combined immunodeficient mice. Cancer Res. 53, $417-422$.

Pyke, C., Ralfkiaer, E., Huhtala, P., Hurskainen, T., Dano, K., and Tryggvason, K. (1992). Localization of messenger RNA for Mr 72,000 and 92,000 type IV collagenases in human skin cancers by in situ hybridization. Cancer Res. 52, 1336 - 1341.

Ray, J.M., and Stetler-Stevenson, W.G. (1994). The role of metalloproteases and their inhibitors in tumor invasion, metastasis and angiogenesis. Eur. Respir. J . 7, 2062 - 2072.

Rouyer, N., Wolf, C., Chenard, M.P., Rio, M.C., Chambon, P., Bellocq, J.P., and Basset, P. (1994). Stromelysin-3 gene expression in human cancer: an overview. Invas. Metast. 14, $269-275$.

Schmitt, M., J änicke, F., and Graeff, H. (1992). Tumor-associated proteases. Fibrinolysis 6, Suppl. 4, 3- 26.

Schultz, R.M., Silberman, S., Persky, B., Bajkowski, A.S., and Carmichael, D.F. (1988). Inhibition by human recombinant tissue inhibitor of metalloproteinases of human amnion invasion and lung colonization by murine B16-F10 melanoma cells. Cancer Res. 48, 5539 - 5545.

Silberman, S., J anulis, M., and Schultz, R.M. (1997). Characterization of downstream Ras signals that induce alternative protease-dependent invasive phenotypes. J . Biol. Chem. 272, $5927-5935$.

Sloane, B.F., and Berquin, I.M. (1993). Proteases and cancer: an introduction. In: Proteolysis and Protein Turnover, J.S. Bond and A.J . Barrett, eds. (London, UK: Portland Press), pp. 225 231.
Stetler-Stevenson, W.G., Liotta, L.A., and Kleiner, D.E. (1993). Extracellular matrix 6: role of matrix metalloproteinases in tumor invasion and metastasis. FASEB J . 7, $1434-1441$.

Tetu, B., Brisson, J ., Lapointe, H., and Bernard, P. (1998). Prognostic significance of stromelysin 3 , gelatinase $A$, and urokinase expression in breast cancer. Hum. Pathol. 29, 979 - 985.

von Marschall, Z., Riecken, E.O., and Rosewicz, S. (1998). Stromelysin 3 is overexpressed in human pancreatic carcinoma and regulated by retinoic acid in pancreatic carcinoma cell lines. Gut 43, 692 - 698.

Watanabe, M., Takahashi, Y., Ohta, T., Mai, M., Sasaki, T., and Seiki, M. (1996). Inhibition of metastasis in human gastric cancercells transfected with tissue inhibitor of metallop roteinase 1 gene in nude mice. Cancer 77, 1676 - 1680.

Werb, Z., Ashkenas, J ., MacAuley, A., and Wiesen, J.F. (1996). Extracellular matrix remodeling as a regulator of stromal-epithelial interactions during mammary gland development, involution and carcinogenesis. Braz. J. Med. Biol. Res. 29, 1087 1097.

Woessner, J.F.J. (1995). Quantification of matrix metalloproteinases in tissue samples. Meth. Enzymol. 248, 510 - 528.

Wright, J .H., McDonnell, S., Portella, G., Bowden, G.T., Balmain, A., and Matrisian, L.M. (1994). A switch from stromal to tumor cell expression of stromelysin-1 mRNA associated with the conversion of squamous to spindle carcinomas during mouse skin tumor progression. Mol. Carcinog. 10, 207 - 215.

Zhang, J .Y., and Schultz, R.M. (1992). Fibroblasts transformed by different ras oncogenes show dissimilar patterns of protease gene expression and regulation. Cancer Res. 52, 6682 - 6689 .

Received J anuary 10, 2000; accepted March 24, 2000 